\section{Global Proceedings Repository \\ American Research Foundation}

ISSN 2476-017X

Available online at http://proceedings.sriweb.org

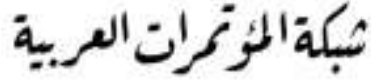

http://arab.kmshare.net/

The Ninth International Scientific Academic Conference

Under the Title "Contemporary trends in social, human, and natural sciences"

$$
\begin{aligned}
& \text { المؤتمر العلمي الاكاديمي الدولي التاسع } \\
& \text { تحت عنوان "الابحاهات المعاصرة في العلوم الاجتماعية، الانسانية، والطبيعية" } \\
& 17 \text { - } 18 \text { يوليو - تموز } 2018 \text { - اسطنبول - تركيا }
\end{aligned}
$$

http://kmshare.net/isac2018/

\title{
The Effectiveness of a Psychological Counseling Program in Alleviating Psychological Alienation and its Impact on Improving the Quality of Life of University Youth in Gaza Governorates
}

\author{
${ }^{1}$ Goltan Hassan Hijazi
}

\begin{abstract}
:
The present study aimed at identifying the nature of the differences in the total score of alienation scale, and quality of life scale among young people in the control group and their counterparts in the experimental group in the posttest, the differences in the overall score of psychological alienation scale and quality of life scale among young people in the experimental group in the pre and post and follow up tests. The sample consisted of twenty nine students of those who obtained the highest scores on the psychological alienation scale, and the lowest scores on the quality of life scale. The study used the psychological alienation scale, the quality of life scale, and the counseling program. The results indicated the success of the counseling program in alleviating psychological alienation and improving the quality of life among university youth.
\end{abstract}

Key words: a Counseling program, psychological alienation, quality of life, youth.

\footnotetext{
${ }^{1}$ A Professor of Mental Health- - Palestine Technical University-West Bank Palestine,Joltanhijazi@gmail.com
} 


\section{Global Proceedings Repository \\ American Research Foundation}

ISSN 2476-017X

Available online at http://proceedings.sriweb.org

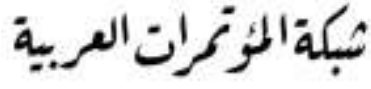

http://arab.kmshare.net/

\section{Introduction of the study:}

Quality of life is one of the most important goals that countries seek to achieve to attain development, prosperity and development, and improving it is a target of social and economic development goals in all societies.

The quality of life is also an important theme in positive psychology, as it is a domain, which gives the individual satisfaction and happiness in light of the current circumstances, potentials, and capabilities available. Today it aims to change the focus of psychology from engaging only in reform or treatment to repairing corrupt things in life in order to build quality of life (Magdy, 2009).

Quality of life is attained when the quality of life of the individual is actualized, as he is the primary target of the educational and psychological efforts seeking to build, and develop him for upgrading the society, and improving life, which is full of turmoil and pressure that hinder one's life, and compromise one's normal interaction with others, and with life (EL-Marhi 2012).

Quality of life reflects the physical and psychological well-being of the human body, the cleanliness and richness of the environment, and satisfaction with the services provided to him, such as education, health services, communications, transportation, democratic practices, social justice, and the spirit of love and optimism among people, high morale, belonging and loyalty to homeland (Mansi and Kazim, 2006).

Ryff et al. (2006) believe that the quality of life is a positive feeling of well-being, gauged by behavioral indicators that reflect high levels of satisfaction of the individual with his life in general, his continuous pursuit of personal valued goals, independence in determining his life, maintaining mutual social positive relations with others. It is associated with the general sense of happiness and enjoyment of life, tranquility and psychological peace of mind, (Karen, Lambour \& Greendpan, 1990). It represents the ability to adopt a lifestyle that meets the wishes of the individual and his needs. Dodson (1994) refers to it as a sense of competence and self-mastery to deal with the challenges. Besides, Adli (2006) indicates that quality of life reflects the emotional state enabling the individual to view himself/herself as able to satisfy his/her different needs and enjoy the circumstances surrounding it.

The World Health Organization (WHOQO, 1995) defines it as the realization of the individual of his status in life in the context of culture and value systems in which he lives and the extent of match or mismatch of this with his goals, expectations, values, interests related to his physical health, psychological condition, the level of his autonomy, social relations, personal beliefs, and his relationship to the environment in general.

Although the majority of researchers agree that quality of life is a primary goal in an individual's life, they disagree about the content and components of quality of life. For instance, WHO (WHOQO, 1998) defines the quality of life components in the following: physical, psychological, social relations, environmental, and religion domains. (Allam, 2012). In addition, Mustafa (2005) selected three dimensions of quality of life as follows: quality of objective life, quality of personal life, and quality of existential life (Abdullah, 2008). Al-Maliki (2011) said that the World Health Organization (2006) issued a Quality of Life Standard that includes the following components: Self-esteem, self-efficacy, independence, positive social relationships, satisfaction with life and happiness.

The sense of the quality of life is a relative concept (Adli, 2006) and varies from person to person both theoretically and practically. It is based on the criteria adopted by individuals to evaluate life and its requirements, which are often affected by many factors controlling the quality of life components, such as the ability to think, make decision- and control and manage ambient conditions, physical and psychological health, economic and social conditions, religious beliefs, cultural and civilizational values. These determine 


\section{Global Proceedings Repository \\ American Research Foundation}

ISSN 2476-017X

Available online at http://proceedings.sriweb.org

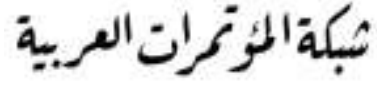

http://arab.kmshare.net/

the individual's most important things that actualize happiness in life (Thunayyan, 2009) .It is enough to attain a certain amount of satisfaction in some aspects of quality of life in a balanced and integrated way to reach a satisfactory level of quality of life (Mesheri 2014).

The quality of life is the product of unique interactions between the individual and life situations (Goode, 1994), so perceiving quality of life is an appropriate reciprocal relation between the requirements of the environment and personal characteristics, and between the individual's awareness of his personal needs and social resources in the environment (Shirawi, 2013). The different experiences undergone by the individual during his life cycle play an important role in the stability of his vision of the quality of his personal life, or changing his life (Allam, 2012), because everyone organizes a private hierarchy of the dimensions of the quality of life according to his priorities. Whenever he moves to a new stage of growth, new requirements are imposed on him and these in turn require the individual to meet the demands of this new stage to attain satisfaction. This makes it a must for the individual to cope with the demands of the new stage, and satisfaction results from success in confrontation and dissatisfaction is caused by the failure to meet needs and failure in the confrontation, in accordance with the quality of life level available to him (Abu Halawa, 2010).

The low sense of life quality in individuals leads to problems of mental disorders, including depression, social isolation and psychological loneliness (Iraqi and Ramadan, 2005), anxiety, fear, aggression, social withdrawal, isolation, and alienation as found out by Vahedi, and Nazari (2011). Additionally, Gupta (2012) discovered a negative relationship between alienation and satisfaction with life.

Recently, the problem of alienation has become one of the most obvious problems (Daugherty \& Lintor, 2003) as it is part of human life whose manifestations affect all facets of cultural and social life (Watfa, 1998). As a result, alienation is gaining more attention and care due to its significance for the life of individuals and its being a standard to gauge mental health of individuals. (Al- Saaidi, 2009).

Alienation is a mental disorder of its manifestations is the individual's sense of not belonging, and therefore he constitutes a danger for society as a whole. It threatens especially the youth sector (El-Ashwal et al, 1985), it is an individual 's sense of non-belonging, the loss of confidence, rejection of social values and norms, suffering from psychological stress, the exposure of personality unity to weakness and collapse , and the impact of cultural and social processes that take place within the community (Zahran, 2002). Besides, it is alienation from society and reality, or the same values and culture, a kind of social separation, a lack of dissatisfaction with reality due to the lack of adaptation to political, economic, social and psychological pressures (Fillia, El-zohairi, 1998). An alienated person is the one who does not feel himself effective, important, and weighty in life. Accordingly, he feels lack of influence on the social situations that he interacts with, and feels that he lacks a mentor or conduct prompt. Similarly, he feels that the value systems that he is subject to have become relatively contradictory, vague and changing. In his relations and social activities, the estranged person feels that he does not achieve himself and is not happy with himself, and therefore tends to isolate and alienate himself from people (Shata, 1993).

The phenomenon of alienation comes as a result of various forms of historical, political, moral, educational and economic repression (Watfa, 1998), reflecting the crisis that contemporary humans face. This reflects the suffering and conflicts resulting from the big gap between the unprecedented accelerated material progress, and the slow advancement in value system and moral progress, making humans suffer from a sense of lack of tranquility, and feel that life has no value or meaning which leads to a sense of and non- belongingness, powerlessness, and meaninglessness (Eid, 1990). The rate of social change that occurs in society leads to a sense of alienation (Abker, 1989). 


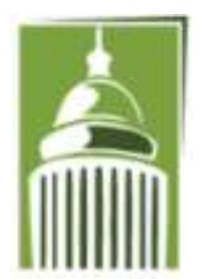

ARF

\section{Global Proceedings Repository \\ American Research Foundation}

ISSN 2476-017X

Available online at http://proceedings.sriweb.org

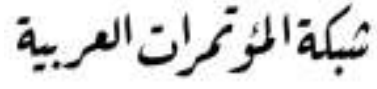

http://arab.kmshare.net/

Researchers pointed out that the feeling of alienation comes because of psychosocial factors related to the psychological and organic development of young people and social factors related to the society in which the individual lives, which makes him unable to overcome the problems of life. Alienation may occur due to the immature interaction between psychological, social, cultural, and economic factors (Al-Asimi, 2002). El-Moghrabi (1973) pointed out that alienation occurs because of the frustrations that surround the individual on each side due to the changes he faces, in which the individual often feels weak, insignificant and powerless. Thus, he feels disappointed and tends to withdraw or isolate himself in a blatant challenge to society and in either case; he feels estrangement (El-Kawaz, Mahmoud, Ali, 2011).

Several factors in the current era have contributed to increasing the feeling of alienation among young people such as globalization, tension, conflict, disruption, selfishness, social crises , migrations and transitions, the attempt of the culture of the strong to dominate the culture of the weak, the openness of the means of communication and lack of controlling them, the loss of value system and normative reference and their meaning in society in which it used to prevail, their transformation into a strange and unacceptable system, the disappearance of cultures, and the emergence of other cultures. All have led to a state of extreme alienation (Ali, 2000).

Additionally, irrational thinking, looking at the various phenomena in an illogical way in terms of their sequence, relations, and mutual interactions , and causes and reasons, distorts the phenomena and make it difficult to understand, control, and guide them in favor of man (Zahran, 2003). He also confirms that psychological barriers that prevent the achievement of individual goals, and conflicts and their associations reflected in aggression and anger, or avoidance or frightened retreat are other causes of alienation.

The dimensions of alienation are social isolation, normlessness, powerlessness, meaninglessness, purposelessness, aggression, rebellion, pessimism, indifference, and lack of affiliation (Hijazi, 2008).

The suffering of young people from alienation results in negative effects represented in drug addiction, assault, aggression, violence, vandalism, absenteeism, alcoholism, crime, the absence from university or school, and suicide (Rayce, Holstein, Kreiner, 2009) besides, refraining from social participation, increasing opposition, clash, indifference, aversion, and addiction (Asaliya 200 1), sense of loneliness and isolation (Sexton, 1983), and a sense of guilt, self - hatred, and a sense of powerlessness, social alienation, grief, autism, the lack of standards, and cultural separation (EL- Daba, and Saud, 2008).These lead to the spread of psychological and mental diseases, sexual degradation, migration of the intellectuals, , armies of mercenaries, and the revolutions of rejection and protest carried out by young people in particular (Mohammed, 2000).

The studies conducted in the Palestinian society including Asaliya's (2001), Hassan's (2003), and Hijazi's (2008) revealed that the Palestinian youth suffer from psychological alienation. Hijazi (2008) confirms that the situation in Palestine is one of the most prominent global conditions contributing to the high level of alienation among Palestinians in general and the youth in particular, by virtue of what Palestinian people have been facing from the Zionist occupation practices in Palestine for more than six decades. These practices have led to expulsion, displacement, murder, destruction, arrest, siege, poverty, unemployment, and the closure of the political horizon. The situation has become very much worse because of the Palestinian disagreements and internal divisions, which have cast a shadow on Palestinian human rights as these accumulated experiences formed pressure affecting negatively the Palestinian youth and increased the sense of alienation among them. 


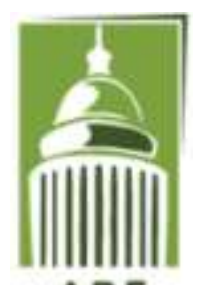

ARF

\section{Global Proceedings Repository \\ American Research Foundation}

ISSN 2476-017X

Available online at http://proceedings.sriweb.org

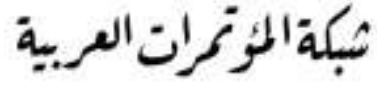

http://arab.kmshare.net/

Moursi (1997) stated that university students suffer most from psychological and social problems, as youth is the time of capabilities related to social and academic life style. It is the stage of setting goals and heading towards them, a stage of searching for the quality of life, and the stage of independence and uniqueness. Their failure to do so leads to many psychological problems. EL-Mansi and Kazim (2006) stressed the university youth need to get physical and psychological health services to enable them to enjoy good health to achieve sense of self - satisfaction and mental health, and their effectiveness in the performance of social roles in the physical and social fields.

Coping with alienation suffered by young people requires addressing the psychological and social causes of it and overcoming them, overcoming feelings of alienation and returning to self and communication with reality, developing the positivity, keeping pace with social change, priding in the national character, developing self-identity and linking it to reality and society, supporting clear and consistent standards, a sense of identity, status, satisfaction, psychological security, integration, solidarity and harmony with the community (Zahran, 2004). Improving the quality of life also requires the development of a range of aspects namely the actualization of oneself , appreciation, satisfying the needs, spotting the positive meaning of life, enjoying social relations and social support, life satisfaction, possessing psychological hardiness, religiosity, a feeling of happiness, and orientation towards the future ( EL Hindawi , 2011).

Orte et al ( 2007) called for paying attention to improving the quality of life through the development of preventive and therapeutic intervention programs and the development of mental health. Abboud (2001) indicated that psychological counseling helps to cleanse the individual from past painful experiences, form healthy human relations, gain collective experiences, and learn new skills that lead to the integration of the individual who feels alienated with members of the group in social relations beyond the borders of the group.

Many of the studies that have addressed the variables of the current study were conducted. Hlaala has conducted (2014) a study aimed at detecting differences in the reasons for the feeling of alienation among university students. The results have proved the presence of statistically significant differences in the reasons for the feeling of alienation among university students due to the variable of sex. The aim of Abu Rasine's study (2012) was to reveal the effectiveness of the proposed training program in improving the quality of life of (31) students of the Educational Diploma at King Khalid University in Abha. The study ended with the success of the program used to improve the quality of life in the study sample. Ognieah's (2012) study aimed to ascertain the effectiveness of a program in improving the quality of life of students of the Libyan University. She conducted the study on a sample of (10) of the students. She concluded there are differences between the pre and post measurements of the quality of life in favor of the post measurement and thus the effectiveness of the program in improving the quality of life. Gupta's (2012) study aimed to explore the relationship between the feeling of loneliness and isolation and quality of life. The study sample consisted of 100 young people between the ages of 18-21 years old. The results revealed the suffering of the sample from a high degree of loneliness. It also revealed the existence of a negative relationship between alienation and quality of life. Nu'aysa (2012) conducted a study to reveal the correlation between the feeling of alienation and psychological security among a sample of 370 students from the University of Damascus. The results showed that the students were suffering from a moderate degree of alienation, the existence of a negative correlation between psychological alienation and a sense of psychological security, and the existence of differences between the ' mean scores on the psychological alienation scale due to gender in favor of Arab students. Mahbob conducted (2012) a study that aimed to examine the effectiveness of the treatment by meaning in the development of mental hardiness and the 


\section{Global Proceedings Repository \\ American Research Foundation}

ISSN 2476-017X

Available online at http://proceedings.sriweb.org

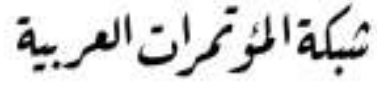

http://arab.kmshare.net/

perception of the quality of life in a sample of blind female adolescents in Mecca. The study sample consisted of 10 adolescents in the experimental group and 10 in the control group. The results showed the presence of statistically significant differences between the mean scores of members of the experimental group in the pre and post application of psychological hardness scale, and the quality of life in favor of the post application. Besides, there were statistically significant differences between the mean scores of the members of the control group and that of the experimental group in the post application of the psychological hardness scale and quality of life in favor of the experimental group. This confirms the effectiveness of the used program. El-Kawaz, and Ali (2011) conducted a study to identify the level of psychological alienation among students of grades 1 and 4 in the Faculty of Physical Education at the University of Mosul. The study sample consisted of (160) students. The study concluded that students did not suffer from psychological alienation, and that there were no significant differences between the first and fourth graders in the following dimensions of alienation: normlessness, powerlessness, and meaninglessness.

Vahedi, and Nazari, (2010) investigated the relationship between alienation and spiritual well being, and life satisfaction among university students. The study sample consisted of 292 students. The findings revealed a negative correlation between each of the sense of spiritual well - being and life satisfaction on one hand, and alienation, and a positive relationship between life satisfaction and spiritual well - being. Abdul Aziz (2008) conducted a study aiming at identifying the quality of life indicators in their relation to mental health among a sample of 400 students from Sohag University. The findings showed the existence of statistically significant relationship between the quality of life and mental health, and the absence of statistically significant differences in the level of quality of life due to gender and majority. The aim of Hijazi's study (2008) was to identify the level of psychological alienation and accomplishment motivation, and the future orientation among Palestinian youth at Al-Aqsa the university. The study sample consisted of 243 male and female students. The study found that $(65 \%)$ of the Palestinian university youth were suffering from psychological alienation, and (25.26\%) from low achievement motivation, and (25.42\%) from the low level of orientation towards the future. Ibrahim and Sadiq's study (2006) aimed to reveal the role of sports activities in the quality of life among the Sultan Qaboos University students. The study sample consisted of 123 male and female students. Sixty -three were engaged in sports activities, and (60) did not practice Sports activities. The results indicated that there were significant differences between the two groups in favor of those exercising sports activities. Makhlouf, and Banat conducted a study (2005) aiming to know the degree of prevalence of the phenomenon of alienation and its relationship with some variables in a sample of (1749) male and female students from Al Quds Open University. The study found the prevalence of the phenomenon of alienation among university students moderate, and that there was variation in the degree of feeling of alienation in its various components represented in the loss values as the most widespread dimension among students. Besides, there were statistically significant differences in the degree of prevalence of alienation due to the social situation, the academic level, the academic program, age, and the cumulative average.

An Iraqi and Ramadan's study (2005) aimed to reveal the effectiveness of a counseling program in improving the quality of life of depressed students. The study sample consisted of (14) students at the Faculty of Education in Banha those with high scores on the Beck scale, low scores on the quality of life scale. The results of the study showed the effectiveness of the counseling program in improving aspects of quality of life among male and female students in the post and delayed measurements. Zahran's study (2003) aimed to examine the effectiveness of a psychological counseling program in correcting alienation beliefs of university students. The study sample consisted of 70 students who got the highest scores on a 


\section{Global Proceedings Repository \\ American Research Foundation}

ISSN 2476-017X

Available online at http://proceedings.sriweb.org

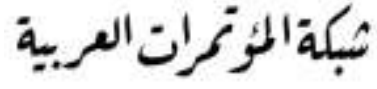

http://arab.kmshare.net/

scale of alienation. The results concluded the success of the program used to reduce feelings and beliefs of alienation. Zahran's study (2002) aimed to study the effectiveness of a cognitive- emotional mental healthcounseling program in correcting the beliefs of alienation in a sample of 310 students from Mansoura University. The study concluded that the program used succeeded to reduce feelings of alienation. Hassan (2003) explored the manifestations of psychological alienation among (408) secondary school students in Gaza. The results of the study concluded that the respondents suffered from feelings of alienation particularly the sense of powerlessness and rejection of society. Abboud (2001) conducted a study aiming at revealing the effectiveness of a counseling program in reducing alienation among adolescent students in boarding schools and children's villages. The study sample consisted of 20 children from the villages of Students (SOS) in Cairo who were equally divided into two homogeneous groups. The results revealed differences in the mean scores of the experimental group in the pre and post application of the scale in favor of the post. There were differences between the mean scores of the experimental group and that of the control group in the alienation scale in favor of the control, indicating the success of the program used to reduce the alienation. Asaliya's study (2001) aimed to identify the differences between unemployed university graduates, and their working colleagues in anxiety and alienation. The results of the study showed the suffering of the unemployed graduates from anxiety and alienation, particularly in the dimensions of meaninglessness, alienation of self, apathy, social isolation, lack of belonging, and aggression. Mahoney and Quick's study ( 2001) aimed to identify the level of alienation among university students in the United States of America, and the impact of sex and the university on the level of alienation, in a sample of (221) male and female students. The results showed the suffering of (77) male and female students of a high degree of alienation.

The review of previous studies has shown that some of them dealt with the variables of the current study, both in their relationship with some variables, or in terms of the pursuit of these studies to develop counseling programs to reduce alienation and improving the quality of life manipulating multiple counseling methods or techniques. Some studies looked into the relationship between alienation and quality of life, and showed a negative correlation between alienation and quality of life. The researcher has noticed that preparation and constructing counseling programs to alleviate alienation and improve the quality of life in the Palestinian environment is an under- researched theme. This encouraged the researcher to conduct this study to fill the gap in this area, and to continue working with the aim of achieving the desired goals represented in improving the mental health of young people. The present study has benefited from previous ones in the formulation of its problem, its questions and hypotheses, the selection of its tools, and the analysis and interpretation of its results.

Young people, who are part of the social structure, are influenced by what is happening around them in various aspects of life. Besides, their roles and statuses are affected by changes, which in turn will definitely influence their future. Therefore, guiding young people and helping them know their identity, accept themselves and their circumstances , and develop their self - confidence and promote affiliation is an urgent need for young people frequently exposed to crises which hinder psychological upgrading and push them to secede from the world around them. Consequently, they begin to feel alienated, which is reflected on their assessment of the quality of life, and this requires counseling programs to identify the guidelines and ways of prevention, and early and effective treatment.

\section{Problem of the study:}

Improving quality of life is one of the most important indicators of the progress of society, as it has become a goal pursued by all societies, and reflects on the satisfaction of the individual, and the sense of happiness. The problem of alienation is one of the challenges facing the young community because of 


\section{Global Proceedings Repository \\ American Research Foundation}

ISSN 2476-017X

Available online at http://proceedings.sriweb.org

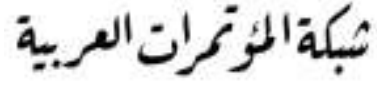

http://arab.kmshare.net/

the complexity of life, and the speed of its rhythm. This results in a lack of security, lack of communication with others, diminished chances of expression, self - realization, a sense of isolation, a sense of guilt, self hatred, a sense of inferiority, and a lack of the ability of the individual to understand the meaning of life and its quality. Thus, alleviation of the manifestations of alienation is an important element in improving the quality of life especially among young people, as they are most important human resources of the societies. They have more energy and efficiency on which the growth of societies largely depends. Hence, this study was to emphasize the role of positive psychology in improving the quality of life by alleviating the psychological alienation among university youth. So the problem of the current study is stated in the following main question:

What is the effectiveness of a psychological counseling program in alleviating psychological alienation and its impact on improving the quality of life of university youth in Gaza governorates?

The following minor questions stem from the above major one:

1. What is the level of psychological alienation, and the quality of life among the youth of the university in the governorates of Gaza?

2. Are there statistically significant differences at the level $(\alpha \leq 0.05)$ between the rank mean scores of the experimental group members and that of their counterparts on the post administration of psychological alienation scale and the quality of life scale?

3. Are there statistically significant differences at the level $(\alpha \leq 0.05)$ between the mean rank scores of the experimental group members and that of their counterparts on the pre and post administration of psychological alienation scale and the quality of life scale?

4. Are there statistically significant differences at the level $(\alpha \leq 0.05)$ between the mean rank scores of the experimental group members on the post and delayed administration of psychological alienation and the quality of life scales?

\section{Objectives of the study:}

The study aimed to identify the level of psychological alienation, and quality of life among the youth of the university in the governorates of Gaza. It also aimed to identify the nature of the differences in the mean ranks of the experimental group and that of the control group on the post administration of psychological alienation and the quality of life scales. Moreover, the study aimed to identify the differences in the mean ranks of the experimental group on the pre and post, and post and delayed administration of psychological alienation and the quality of life scales.

\section{The importance of study:}

The importance of the study lies in the following:

1. This study addresses an important group namely the class of young people who represent a powerful sector of the community in the building process and change for a better future.

2. The importance of the subject matter of the study, which is psychological alienation and its causes. It leads to the emergence of psychological problems that deplete potentialities and energies of young people. Moreover, quality of life is a goal for which all societies strive as one of the goals of the twenty - first century.

3. The importance of the study lies in the preparation of the study tools that can be used in future psychological studies.

4. The practical significance of the study lies in that it will provide a counseling program that may contribute to training young people and equipping them with new training methods and strategies 


\section{Global Proceedings Repository \\ American Research Foundation}

ISSN 2476-017X

Available online at http://proceedings.sriweb.org

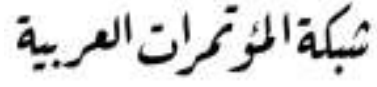

http://arab.kmshare.net/

that will help them alleviate psychological alienation and improve the quality of life. The study will provide data and information in the field of constructing therapeutic programs for young people who suffer from alienation and low level of quality of life, especially since there is a dearth of such studies in the Palestinian environment, and will open the way for counselors and specialists to guide the youth and help them.

5. The results of this study can help in the development of educational plans and programs, especially by governmental and non - governmental institutions concerned with youth, in order to provide better psychological and educational services to take care of them, which will reflect positively on the mental health of the young.

\section{Terminology of study}

Psychological alienation: The researcher defines it as the individual's sense of rebellion, powerlessness, social isolation, rejection of social values and norms, the loss of the meaning of life, pessimism, indifference, and lack of belonging. It is operationally defined as the score obtained by a university student on the scale used in the study.

Quality of Life: The researcher defines it as satisfaction of the individual with his life, and enjoying physical, mental and emotional health, social self-efficacy, psychological hardiness, being successful , achieving one's aspirations, having self-confidence, being optimistic, sticking to one's values, belonging to homeland, and heading towards the future. The researcher operationally defines it as the score obtained by a university student on the scale of quality of life used in the study.

Youth: It is the period between adolescence and adulthood. The period is determined by the end of the second decade or the beginning of the third decade of life. It is operationally defined in the current study as the students of the Al- Aqsa University in the Gaza Strip who are aged between 18-22 years.

Counseling Program: It is a planned organized program in the light of scientific principles. It aims to provide counseling services for the university youth individually and collectively in order to help them alleviate psychological alienation and improve the quality of life. It depends on multiple techniques, including: cognitive reconstruction, relaxation, role-play, debate, lecture, group discussion, self - control, sports exercises, and homework.

\section{Limitations of the study:}

The current study manipulates the experimental method on the basis that the independent variable is the counseling program, which the study seeks to determine its effectiveness in the relief of psychological alienation and its impact on improving the quality of life. The study is determined by the tools used, namely psychological alienation scale, the quality of life scale, the counseling program prepared by the researcher, the sample used in the study consisting of ( 300 ) male and female students from Al- Aqsa University, and the treatment sample consisting of 29 male and female students . The researcher divided them into homogeneous experimental group of (14), a control of (15). The spatial limit is represented in the application of scales used and the counseling program at Al- Aqsa University. The time limits is represented in the fact that the program was implemented during the period from the beginning of October until the end of December ( 2015 ). The follow up test took place after two months (February 2016). 


\section{Global Proceedings Repository \\ American Research Foundation}

ISSN 2476-017X

Available online at http://proceedings.sriweb.org

\section{Hypotheses of the study:}

The present study tests the following hypotheses:

1- There are no statistically significant differences at the level of $(A \leq 0.05)$ between the mean rank scores of members of the experimental group and that of their counterparts in the control group on the post administration of psychological alienation and quality of life scales.

2- There are no statistically significant differences at the level of $(\mathrm{A} \leq 0.05)$ between the mean rank scores of members of the experimental group on pre and post administration of psychological alienation and quality of life scales.

3- There are no statistically significant differences at the level of $(\mathrm{A} \leq 0.05)$ between the mean rank scores of members of the experimental group on the post and delayed administration of

\section{Methods and procedures:} psychological alienation and quality of life scales.

This section includes a description of the method and procedures of the study, in terms of the approach, the sample, the tools and statistical treatment.

\section{First: Methodology of the study:}

The study used:

The descriptive approach: which depends on the description and comparison to describe what the reality, and interpret it by identifying the problem, closely understanding the present circumstances, and collecting information that increase the clarity of the problem of the study and the surrounding circumstances.

Experimental approach: the experimental design was used as two groups were formed: experimental and control group, the experimental group was exposed to the counseling program, while the control group was not exposed to any intervention. Results were compared on the pre and post administration of the scales in both the treatment and control groups.

\section{Second: The study sample:}

The sample of the descriptive study: The sample of the descriptive study consisted of (300) of AlAqsa University male and female students, who were randomly selected. The pre application of the scales was administered to them.

The pilot study sample: In the beginning, the pilot study sample consisted of (30) male and female students with the highest scores on the psychological alienation scale, and the lowest scores on the quality of life scale used in the study. The distribution of female students into two groups was accomplished using random numbers. One experimental and the second control each included (15). The homogeneity of the two groups was ensured in terms of pre and post implementation of psychological alienation, and the quality of life scales, and the economic and social level form, (prepared : Abu Mustafa, 2010 ). The withdrawal of one of the students from the experimental sample reduced its number to (14), and the total number of the sample became ( 29 students). The following table show this.

Table (1)Mann -Whitney Test to identify differences between the mean scores of the control and experimental groups in two measurements of psychological alienation scale.

\begin{tabular}{cccccccc}
\hline \hline Measurement & group & number & Rank mean & $\begin{array}{c}\text { Rank } \\
\text { sum }\end{array}$ & $\begin{array}{c}\text { Z } \\
\text { value }\end{array}$ & $\begin{array}{c}\text { statistical } \\
\text { sig }\end{array}$ & $\begin{array}{c}\text { Nature of } \\
\text { sig }\end{array}$ \\
\hline \hline Pre & $\begin{array}{c}\text { Control } \\
\text { experimenta } \\
1\end{array}$ & 15 & 15.9 & 239 & & & Non \\
\cline { 3 - 5 } & 14 & 14 & 196 & 0.617 & 0.537 & $\begin{array}{c}\text { Non } \\
\text { existent }\end{array}$ \\
\hline \hline
\end{tabular}


ISSN 2476-017X

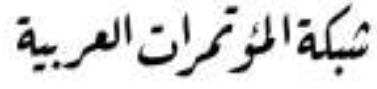

http://arab.kmshare.net/

Available online at http://proceedings.sriweb.org

Table (2)Mann -Whitney test to identify differences between the mean scores of the control and experimental groups in two measurements of quality of life scale.

\begin{tabular}{|c|c|c|c|c|c|c|c|}
\hline Measurement & group & number & Rank mean & $\begin{array}{c}\text { Rank } \\
\text { sum }\end{array}$ & $\begin{array}{c}\mathrm{Z} \\
\text { value }\end{array}$ & $\begin{array}{c}\text { statistical } \\
\text { sig } \\
\end{array}$ & $\begin{array}{c}\text { Nature of } \\
\text { sig }\end{array}$ \\
\hline \multirow{2}{*}{ Pre } & \multirow{2}{*}{$\begin{array}{c}\text { Control } \\
\text { experimenta } \\
1\end{array}$} & 15 & 17.9 & 268 & \multirow{2}{*}{1.88} & \multirow{2}{*}{0.06} & \multirow{2}{*}{$\begin{array}{c}\text { Non } \\
\text { existent }\end{array}$} \\
\hline & & 14 & 11.9 & 167 & & & \\
\hline
\end{tabular}

Table (3)Mann -Whitney test to identify differences between the mean scores of the control and experimental groups in the socio economic level.

\begin{tabular}{|c|c|c|c|c|c|c|c|}
\hline Measurement & group & number & Rank mean & $\begin{array}{l}\text { Rank } \\
\text { sum }\end{array}$ & $\begin{array}{c}\mathrm{Z} \\
\text { value }\end{array}$ & $\begin{array}{c}\text { statistical } \\
\text { sig }\end{array}$ & $\begin{array}{c}\text { Nature of } \\
\text { sig }\end{array}$ \\
\hline \multirow[b]{2}{*}{ Pre } & \multirow{2}{*}{$\begin{array}{c}\text { Control } \\
\text { experimenta } \\
1\end{array}$} & 15 & 14.3 & 214.5 & \multirow[b]{2}{*}{0.465} & \multirow[b]{2}{*}{0.642} & \multirow{2}{*}{$\begin{array}{c}\text { Non } \\
\text { existent }\end{array}$} \\
\hline & & 14 & 15.75 & 220.5 & & & \\
\hline
\end{tabular}

\section{Third: Study Tools:}

The study used the psychological alienation, and the quality of life scales, and the counseling program prepared by the researcher. The following is a presentation:

1-The psychological alienation scale (Hijazi, 2008):

Description of the Scale: It consists of 65 items, measuring eight domains as follows: 1-Rebellion :( 110). 2. Powerlessness :(11-17). 3. Isolation: (18-26). 4-normlessness: (27-36). 5-meaninglessness: (37-44). 6. Pessimism: (45-53). 7. Indifference (54-59). 8. Non-belongingness (60-65). The responses were corrected according to the following scale: (3) points for agree, (2) points for not sure, (1) point for Do not agree. The scale reliability in the original study was ensured by using the split-half method and reached (0.87), and according to the Cronbach equation was (0.92).

\section{The scale Validity:}

The validity of the scale is calculated by:

Construct validity indicators: The scale was administered to a pilot sample consisting of (50) of the university students. Consistency between the items of the scale and the total score of the scale was calculated. Correlation coefficients of the scale items were significant at 0.01. The following table shows this:

Table (4)Shows the correlation between the score of every item and the total score of the scale.

\begin{tabular}{cccccccccc}
\hline \hline Item No & $\begin{array}{c}\text { Sig } \\
\text { level }\end{array}$ & Item No & $\begin{array}{c}\text { Sig } \\
\text { level }\end{array}$ & Item No & $\begin{array}{c}\text { Sig } \\
\text { level }\end{array}$ & Item No & $\begin{array}{c}\text { Sig } \\
\text { level }\end{array}$ & Item No & $\begin{array}{c}\text { Sig } \\
\text { level }\end{array}$ \\
\hline \hline 1. & $0.647^{* *}$ & 15 & $0634^{* *}$ & 29 & $0.661^{* *}$ & 43 & $0.747^{* *}$ & 57 & $0.609^{* *}$ \\
\hline 2. & $0.02^{* *}$ & 16 & $0.322^{* *}$ & 30 & $0.585^{* *}$ & 44 & $0.609^{* *}$ & 58 & $0.6610^{* * *}$ \\
\hline 3. & $0.587^{* *}$ & 17 & $0.737^{* *}$ & 31 & $0.609^{* *}$ & 45 & $0.661^{* *}$ & 59 & $0.585^{* *}$ \\
\hline 4. & $0.642^{* *}$ & 18 & $0.617^{* *}$ & 32 & $0.661^{* *}$ & 46 & $0.585^{* *}$ & 60 & $0.661^{* *}$ \\
\hline 5. & $0.748^{* *}$ & 19 & $0.322^{* *}$ & 33 & $0.585^{* *}$ & 47 & $0.436^{* *}$ & 61 & $0.585^{* *}$ \\
\hline 6. & $0.634^{* *}$ & 20 & $0.737^{* *}$ & 34 & $0.617^{* *}$ & 48 & $0.585^{* *}$ & 62 & $0.609^{* *}$ \\
\hline 7. & $0.647^{* *}$ & 21 & $0.617^{* *}$ & 35 & $0.322^{* *}$ & 49 & $0.436^{\text {** }}$ & 63 & $0.661^{\text {** }}$ \\
\hline 8. & $0.324^{* *}$ & 22 & $0.322^{* *}$ & 36 & $0.737^{* *}$ & 50 & $0.747^{* *}$ & 64 & $0.585^{* *}$ \\
\hline 9. & $0.642^{* *}$ & 23 & $0.737^{* *}$ & 37 & $0.609^{* *}$ & 51 & $0.661^{* *}$ & 65 & $0.661^{* *}$ \\
\hline \hline
\end{tabular}




\section{Global Proceedings Repository \\ American Research Foundation}

ISSN 2476-017X

Available online at http://proceedings.sriweb.org

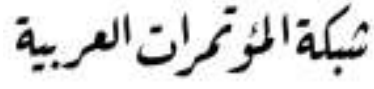

http://arab.kmshare.net/

\begin{tabular}{llllllll}
\hline \hline 10. & $0.647^{* * *}$ & 24 & $0.609^{* *}$ & 38 & $0.661^{* * *}$ & 52 & $0.585^{* * *}$ \\
\hline 11. & $0.602^{* *}$ & 25 & $0.661^{* *}$ & 39 & $0.585^{* *}$ & 53 & $0.661^{* *}$ \\
\hline 12. & $0.587^{* *}$ & 26 & $0.585^{* *}$ & 40 & $0.436^{* *}$ & 54 & $0.585^{* *}$ \\
\hline 13. & $0.642^{* * *}$ & 27 & $0.585^{* *}$ & 41 & $0.585^{* *}$ & 55 & $0.661^{* * *}$ \\
\hline 14. & $0.748^{* * *}$ & 28 & $0.609^{* *}$ & 42 & $0.436^{* *}$ & 56 & $0.585^{* *}$ \\
\hline \hline
\end{tabular}

Scale Reliability:

The researcher calculated reliability in several ways:

Reliability by split-half method:

The scale was applied to a pilot sample consisting of (50) of the university students. The reliability coefficient between the odd and even items was computed. The following table illustrates this:

Table (5) shows the reliability coefficients using the split-half method of the psychological alienation scale

\begin{tabular}{|l|c|}
\hline Odd values & 0.947 \\
\hline Even values & 0.939 \\
\hline Gateman coefficient & 0.983 \\
\hline
\end{tabular}

Using Spearman- Brown equation, the reliability coefficient value reached 0.99 which indicates a high degree of reliability of the scale.

\section{Reliability using Cronbach- Alpha:}

The internal consistency coefficient (alpha - A) regarding the results of the pilot sample, and (A) equaled (0.971), which is an acceptable statistical level of reliability.

\section{2- The quality of life scale:}

After reviewing educational literature, and a number quality of life scales, including Azab's scale (2004), Mansi and Kazim's (2006), Abdullah's (2008), Abu Ghali and Abu Mustafa's (2012), the researcher constructed the scale. The final version of the scale consisted of (50) items distributed on the following domains, physical (1-10), psychological (11-20), social (21-30), academic (31-40), and the general sphere of the quality of life (41-50).

Scale Correction: The scale was corrected according to a four - grading options as follows: Always (4), often (3), sometimes (2), rarely (1).

Validity of the scale:

Arbitrators' validity: The researcher introduced the scale to (10) arbitrators specialized in mental health and psychological counseling, to identify the appropriacy of the scale items and the extent they represent the aspects involved. The scale was presented in its preliminary form composed of 55 items. Arbitrators excluded (5) items. Thus the final version of the scale consists of (50) items.

Construction validity indicators: The scale was administered to a pilot sample comprising 50 university students. The correlation coefficient of the scale items, and the total score of the scale. The results of correlation coefficients for all items of the scale were significant at 0.01 . The following table shows that:

Table (6) shows the correlation coefficients between the score of each item with the total score of the scale

\begin{tabular}{|c|c|c|c|c|c|c|c|c|c|}
\hline $\begin{array}{c}\text { Item } \\
\text { No }\end{array}$ & Sig level & $\begin{array}{c}\text { Item } \\
\text { No }\end{array}$ & Sig level & $\begin{array}{c}\text { Item } \\
\text { No }\end{array}$ & Sig level & $\begin{array}{c}\text { Item } \\
\text { No }\end{array}$ & Sig level & $\begin{array}{c}\text { Item } \\
\text { No }\end{array}$ & Sig level \\
\hline 1 & $0.823^{* * *}$ & 11 & $0.538^{* * 3}$ & 21 & $0.688^{* * *}$ & 31 & $0.728^{* * *}$ & 41 & $0487^{* * 3}$ \\
\hline 2 & $0.872^{* * *}$ & 12 & $0.487^{* * *}$ & 22 & $0.841^{* * *}$ & 32 & $0.755^{* * *}$ & 42 & $0.700^{* * *}$ \\
\hline 3 & $0.587^{* * 6}$ & 13 & $0.734^{\text {*** }}$ & 23 & $0.827^{\text {*** }}$ & 33 & $0.416^{* *}$ & 43 & $0.726^{* * *}$ \\
\hline 4 & $0.871^{* * *}$ & 14 & $0.604^{* * *}$ & 24 & $0.728^{* *}$ & 34 & $0.601^{* *}$ & 44 & $0.795^{* * *}$ \\
\hline 5 & $0.605^{* *}$ & 15 & $0.634^{\text {** }}$ & 25 & $0.651^{* * 6}$ & 35 & $0.399^{* * *}$ & 45 & $0.767^{* * 3}$ \\
\hline
\end{tabular}




\section{Global Proceedings Repository \\ American Research Foundation}

ISSN 2476-017X

Available online at http://proceedings.sriweb.org

\begin{tabular}{clllllllll}
\hline \hline 6 & $0.889^{* *}$ & 16 & $0.674^{* *}$ & 26 & $0.728^{* * *}$ & 36 & $0.766^{* *}$ & 46 & $0.756^{* * *}$ \\
\hline 7 & $0.611^{* * *}$ & 17 & $0.628^{* * *}$ & 27 & $0.585^{* *}$ & 37 & $0.450^{* *}$ & 47 & $0.484^{* *}$ \\
\hline 8 & $0.889^{* * *}$ & 18 & $0.722^{* * *}$ & 28 & $0.658^{* * *}$ & 38 & $0.706^{* * *}$ & 48 & $0.687^{* *}$ \\
\hline 9 & $0.509^{* * *}$ & 19 & $0.654^{* * *}$ & 29 & $0.460^{* * *}$ & 39 & $0.609^{* * *}$ & 49 & $0.473^{* *}$ \\
\hline 10 & $0.888^{* * *}$ & 20 & $0.564^{* *}$ & 30 & $0.422^{* *}$ & 40 & $0.573^{* *}$ & 50 & $0.753^{* *}$ \\
\hline \hline
\end{tabular}

\section{Scale Reliability:}

The researcher ensured the scale reliability using the following ways:

Split - half method: The scale was administered to a pilot sample consisting of 50 university students. Reliability coefficients between the odd items and even ones, the total score and domains were computed. The following table illustrates this:

Table (7) shows the reliability coefficients of the quality of life scale using the split-half method.

\begin{tabular}{ccccc}
\hline \hline Domains & Odd value & Even value & Jet man & Reliable coeff. \\
\hline \hline Physical & 0.815 & 0.972 & 0.818 & 0.899 \\
\hline Psychological & 0.856 & 0.76 & 0.878 & 0.94 \\
\hline Social & 0.754 & 0.716 & 0.917 & 0.96 \\
\hline Academic & 0.824 & 0.579 & 0.5 & 0.7 \\
\hline General & 0.852 & 0.654 & 0.8 & 0.89 \\
\hline \hline
\end{tabular}

The previous table indicates a high degree of reliability.

Reliability using Cronbach- Alpha: To ensure the scale reliability, its internal cohesion, and the internal consistency coefficient (alpha - A) was computed in a pilot sample. Reliability coefficient was computed, and the following table illustrates this:

Table (8) shows the reliability coefficients using Cronbach- alpha the quality of life scale

\begin{tabular}{cc}
\hline \hline Domains & Alpha Reliability coeff \\
\hline \hline Physical & 0.93 \\
\hline Psychological & 0.85 \\
\hline Social & 0.86 \\
\hline Academic & 0.77 \\
\hline General & 0.85 \\
\hline \hline
\end{tabular}

The previous table indicates a high degree of reliability of the scale.

\section{3- The counseling program:}

This program is one of the basic tools that developed to alleviate psychological alienation and improve the quality of life among university youth. It is a therapeutic collective counseling program that includes a variety of techniques. It is a set of steps and procedures provided for young people. It was implemented through (23) sessions, and was administered to a sample of young people comprising (29 students) during the period from the beginning of October to the end of December 2015, at a rate of two sessions per week. The follow up application took place after two months (February 2016).

\section{The overall objective of the program:}




\section{Global Proceedings Repository \\ American Research Foundation}

ISSN 2476-017X

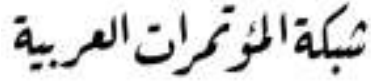

http://arab.kmshare.net/

Available online at http://proceedings.sriweb.org

Alleviating psychological alienation and improving the quality of life of the university Palestinian youth.

2. Specific objectives:

- Cognitive objectives:

- clarifying the meaning of psychological alienation, and quality of life.

-Identifying the quality of life indicators, and its components.

-Modifying irrational beliefs, and replacing them with rational ones.

-The development of positive thinking and problem - solving skills.

- Emotional goals:

- Getting rid of the feelings of alienation.

-Developing attitudes and feelings of optimism loaded by happiness and hope.

-Strengthening self-confidence and developing independence.

-Respect for the values and traditions of society.

-Developing flexibility and moderation and avoiding intolerance and rigidity.

-Promoting a positive self-concept and the development of cooperative behavior, leadership and decision making.

-The development of life satisfaction, and helping students to accept themselves.

- Behavioral objectives:

-Reducing feelings of alienation and the development of feelings of belongingness.

- Training the participants to practice positive behaviors.

- Helping participants to acquire social skills.

- Training participants to relax and do sports exercises.

-cultivating effective social participation among the members of the group.

3. Counseling method used in the program:

The researcher used the collective guidance method in the implementation of this program. She, however, resorted to individual sessions with some students when necessary.

\section{4 -Techniques used in the program:}

The researcher diversified the techniques and the strategies used in the program. so the program will include multiple techniques such as A-B-C, cognitive imagination, Homework Technique, lecture, group discussion, role playing, modeling, debate ,relaxation, style problem solving, reinforcement, a training on social skills, and sports exercises .

5-Program Arbitration: The counseling program initial version was given to (10) of professors of psychology, mental health and psychological counseling, to judge the validity of its procedures, and ensure its suitability for administration. The researcher implemented the modifications required. Then she prepared the final version of the program that aimed at alleviating the psychological alienation, and improve the quality of life of the Palestinian youth.

6-Program Evaluation: The program was evaluated by applying the psychological alienation, and the quality of life scales, comparing the results of the experimental and control groups in pre and post administration, and then comparing the results of the experimental group in the pre and post, and post and delayed administration.

7-The program sessions: The session's content was selected in accordance with the objectives that have been identified in the program, as well as the techniques and methods used in the program. The researcher has taken into account a set of criteria in the selection of the content of the sessions such as using clear and understandable words and phrases, the logical sequencing in the provision of concepts and skills, considering the participants' characteristics, and diversification of the techniques and activities. The 


\section{Global Proceedings Repository \\ American Research Foundation}

ISSN 2476-017X

Available online at http://proceedings.sriweb.org

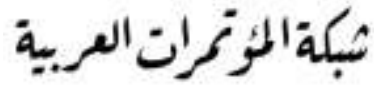

http://arab.kmshare.net/

program was implemented in (2 3) session, at the rate of two per week, and session length ranged between (60-90) minutes.

Statistical methods: The study used the following statistic techniques of relative weight, the arithmetic mean, standard deviation, Pearson correlation coefficient, alpha- Cronbach coefficient, Wilcoxon test, and Mann-Whitney test.

\section{Results:}

The results of the first and second questions:

The results of the first question:

1.What is the level of psychological alienation, and the quality of life among the university youth of governorates of Gaza?

To answer this question, the researcher calculated arithmetic means, standard deviations, and relative weights of the alienation and quality of life scales of the sample. The following table illustrates this:

Table (9)Arithmetic means, standard deviations, and the relative weights of the alienation scale total score, and total score of the quality of life scale, and its domains

\begin{tabular}{ccccc}
\hline \hline Domains & Sample No & Athematic mean & Stander deviation & Relative weight \\
\hline \hline Physical & 358 & 26.4525 & 3.6124 & $60.12 \%$ \\
\hline Psychological & 358 & 22.5391 & 3.34854 & $56.35 \%$ \\
\hline Social & 358 & 17.8492 & 5.21253 & $44.62 \%$ \\
\hline Academic & 358 & 23.8939 & 4.36114 & $59.73 \%$ \\
\hline General & 358 & 23.0670 & 3.93376 & $57.67 \%$ \\
\hline Total score & 358 & 113.8017 & 14.75694 & $51.73 \%$ \\
\hline Alienation total score & 358 & 180.1000 & 6.36000 & $69.27 \%$ \\
\hline
\end{tabular}

The above table shows that the quality of life level in study sample is low in all domains and the total score of the scale as well. The domains range between $(60.12 \%)$ and $(44.62 \%)$, and the total score $(51.73 \%)$. There is a high level of feeling of alienation in the sample, as the scale total score reaches $(69.27 \%)$, which is a high percentage.

These findings are consistent with those of Asaliya (2002), Hassan (2003), Makhlouf, and Banat (2005), and Hijazi (2008), which confirmed that the Palestinian youth suffer from feelings of estrangement. The findings differ from those of El - Adli (2006), which proved that the university students enjoy a high sense of quality of life.

The researcher attributes the high level of feeling of alienation and low quality of life among the university youth to the political, economic and social conditions in which these young people live. Closure of political horizon, the spread of poverty and unemployment, the siege and closure, division, and the unknown future deprived these young people from meeting needs and demands of their daily life, and organizing their future in terms of work, marriage and stability. Therefore, they feel a sense of despair, frustration, pessimism, and powerlessness. Asaliya confirms (200 1) that the Palestinian youth suffer from the loss of a minimal sense of reassurance that deepens the sense of alienation. Young people experience a higher sense of suffering and frustration than others do by virtue of their age, lack of experience, and looking forward to a better life let alone the urgent need to achieve their presence and prove themselves.

Exposure of young people in the provinces of Gaza to traumas, shocks, pressures as a result of repeated wars, and the perception of not being able to confront them, or to predict the results contributed a lot to making them feel powerlessness, despair, pessimism, loss of meaning of life, and increasing alienation. This finding confirms the results of Hassan, (2003) on the presence of a positive correlation between violence and alienation. 


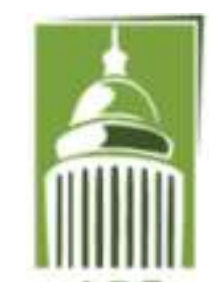

ARF

\section{Global Proceedings Repository \\ American Research Foundation}

ISSN 2476-017X

Available online at http://proceedings.sriweb.org

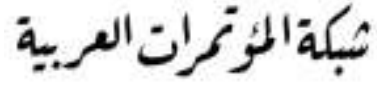

http://arab.kmshare.net/

Reality in the Gaza Strip because of the policies of occupation does not tell of an imminent breakthrough in political, economic, security and social challenges in addition to the circumstances and indicators associated with the dramatic factors of unknown nature. Experiences young people live today and deteriorating state of affairs make the young feel disappointment, frustration and pessimism. This leads to a sense of powerlessness, anxiety, discomfort, fear, a sense of loss, and loss of identity. The developmental Studies Program (1999) confirmed this finding, which indicated that the Israeli occupation creates despair among young people, and deprives them of a better future. They always have a sense of fear of poverty. It is an obstacle to their physical and mental development. They lack purpose and hope for the future. Hijazi 'study, and Abu Ghali, and Mehdi's (2016) indicated that young Palestinians were significantly suffering from a multi - type crisis. The descending order: economic crises $(85.51 \%)$, political crises $(81.22 \%)$, academic crises $(78.88 \%)$, cultural and social crises $(77.46 \%)$, security crises $(75.44 \%)$, and psychological crises (74.53\%). Asaliya (2001) stated that the individual's sense of alienation towards the society to which he belongs creates crises inside him and these in turn create alienation. Khulaifi also asserted (1998) that crises and social pressures, pressures of life, traumatic events like war and disasters influence the reality of young people and their future, and increase the suffering of young people from symptoms such as anxiety, a sense of insecurity, fear of the future, and a sense of alienation. Also El-Ssahl and Hanorh (1998) asserted the existence of a positive correlation between the high sense of shock and high sense of alienation, and a sense of powerlessness, meaninglessness, apprehension and sense of threat from the future.

The suffering of young people from all the previous circumstances has contributed, in addition to the pressures of age and school stage, to increasing the sense of anxiety ' depression, loss of security, nervousness, low morale, and low motivation. All these factors contribute to increasing the level of alienation and poor level of quality of life. Abdullah (2008) stressed that the mental health factors predict the level of quality of life with its various domains.

\section{Second, the results of hypotheses related to the counseling program: The results of the first hypothesis, which states:}

"There are no statistically significant differences at the level of $(\mathrm{A} \leq 0.05)$ between the mean rank scores of members of the experimental group and that of their counterparts in the control group on the post administration of psychological alienation and quality of life scales". To ensure the validity of the hypothesis, Mann-Whitney test was used to calculate the significance of differences between the mean scores of two different samples, and the following two tables show this.

Table (10)Mann -Whitney test to identify the differences between the mean scores of the control and experimental samples in the post administration of the psychological alienation scale.

\begin{tabular}{cccccccc}
\hline \hline Measurement & group & number & $\begin{array}{c}\text { Rank } \\
\text { mean }\end{array}$ & $\begin{array}{c}\text { Rank } \\
\text { sum }\end{array}$ & Z value & $\begin{array}{c}\text { statistical } \\
\text { sig }\end{array}$ & $\begin{array}{c}\text { Nature of } \\
\text { sig }\end{array}$ \\
\hline \hline $\begin{array}{c}\text { psychological } \\
\text { alienation }\end{array}$ & $\begin{array}{c}\text { Control } \\
\text { experimental }\end{array}$ & 15 & 22 & 330 & \multirow{2}{*}{4.594} & 0.000 & $\begin{array}{c}\text { Non } \\
\text { existent }\end{array}$ \\
\hline \hline
\end{tabular}

The above table shows the existence of statistically significant differences at the level $(0.05)$ in the mean scores of the post administration of psychological alienation scale between the control group and experimental group. The alienation level decreased in the experimental group (7.5) than among the control group (22). This finding confirms the effectiveness of the counseling program used and the success of the techniques used to mitigate the level of psychological alienation of the experimental sample.

Table (11)Mann -Whitney test to identify the differences between the mean scores of the control and experimental samples in post administrations scale quality of life scale 


\section{Global Proceedings Repository \\ American Research Foundation}

ISSN 2476-017X

Available online at http://proceedings.sriweb.org

ARF

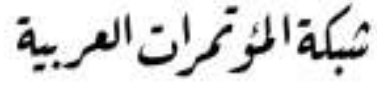

http://arab.kmshare.net/

\begin{tabular}{|c|c|c|c|c|c|c|c|}
\hline Measurement & group & number & $\begin{array}{l}\text { Rank } \\
\text { mean } \\
\end{array}$ & $\begin{array}{c}\text { Rank } \\
\text { sum }\end{array}$ & $Z$ value & $\begin{array}{c}\text { statistical } \\
\text { sig } \\
\end{array}$ & $\begin{array}{c}\text { Nature of } \\
\text { sig }\end{array}$ \\
\hline $\begin{array}{c}\text { quality of life } \\
\text { scale }\end{array}$ & $\begin{array}{c}\text { Control } \\
\text { experimental }\end{array}$ & $\begin{array}{l}15 \\
14\end{array}$ & $\begin{array}{c}8.1 \\
22.4\end{array}$ & $\begin{array}{l}121 \\
314\end{array}$ & 4.54 & 0.000 & $\begin{array}{c}\text { Non } \\
\text { existent }\end{array}$ \\
\hline
\end{tabular}

The above table showed the presence of statistically significant differences at the level (0.05) in the mean scores of the post administration of the quality of life scale between the control group and experimental group. Life quality level increased in the experimental sample with mean rank score of (22.4) whereas that of the control sample was (8.1), which emphasizes the effectiveness of the counseling program used and the success of the techniques used to improve the quality of life level of the experimental sample.

The results of the second hypothesis, which states:

" There are no statistically significant differences at the level of ( $\mathrm{A} \leq 0.05)$ between the rank mean scores of the experimental group subjects on pre and post administration of psychological alienation and the quality of life scales". To ensure the validity of the hypothesis, Wilcoxon test was used to calculate the significance of differences between the mean scores of one sample, and the following tables illustrate this:

Table (12)Wilcoxon test to denote differences between the mean scores of the experimental sample in pre and post administration of psychological alienation scale

\begin{tabular}{|c|c|c|c|c|c|c|c|c|}
\hline Measurement & group & number & $\begin{array}{l}\text { Rank } \\
\text { mean }\end{array}$ & $\begin{array}{c}\text { Rank } \\
\text { sum }\end{array}$ & $\begin{array}{c}\mathrm{Z} \\
\text { value }\end{array}$ & $\begin{array}{c}\text { Statistical } \\
\text { sig }\end{array}$ & $\begin{array}{c}\text { Eta } \\
\text { square }\end{array}$ & $\begin{array}{c}\mathrm{D} \\
\text { Value }\end{array}$ \\
\hline $\begin{array}{l}\text { Pre } \\
\text { Post }\end{array}$ & $\begin{array}{c}\text { Control } \\
\text { experimental }\end{array}$ & $\begin{array}{c}14 \\
0\end{array}$ & $\begin{array}{c}7.5 \\
0\end{array}$ & $\begin{array}{c}105 \\
0\end{array}$ & 3.298 & 0.001 & 0.7311 & 0.519 \\
\hline
\end{tabular}

It is evident from the table above that there are significant differences between the experimental group sample's mean scores in the pre and post administration at the level (0.01) in the total score for the psychological alienation scale. The level of psychological alienation among university young people in the experimental group lowered after the administration of the counseling program, which confirms its success and effectiveness in alleviating psychological alienation.

Table (13)Wilcoxon test to denote differences between the mean scores of the experimental sample in the pre and post administration of the quality of life scale

\begin{tabular}{ccccccccc}
\hline \hline Measurement & group & number & $\begin{array}{c}\text { Rank } \\
\text { mean }\end{array}$ & $\begin{array}{c}\text { Rank } \\
\text { sum }\end{array}$ & $\begin{array}{c}\text { Z } \\
\text { value }\end{array}$ & $\begin{array}{c}\text { Statistical } \\
\text { sig }\end{array}$ & $\begin{array}{c}\text { Eta } \\
\text { square }\end{array}$ & $\begin{array}{c}\text { D } \\
\text { value }\end{array}$ \\
\hline \hline \multirow{2}{*}{ quality of life } & Positive & 14 & 7.5 & 105 & \multirow{2}{*}{3.298} & 0.001 & 0.730 & 0.519 \\
\cline { 2 - 6 } & negative & 0 & 0 & 0 & & 0.019 \\
\hline \hline
\end{tabular}

It is evident from the table above that there are statistically significant differences between the mean scores of the experimental sample in the pre and post administration at the level (0.01) in the total score of life quality scale. The life quality level rose after the administration of the counseling program to the members of the experimental group.

The results of the third hypothesis, which states:

"There are no statistically significant differences at the level of $(\mathrm{A} \leq 0.05)$ between the mean rank scores of members of the experimental group on and post and delayed administration of psychological alienation and quality of life scales". To ensure the validity of the hypothesis, Wilcoxon test was used to calculate the significance of differences between the mean scores of one sample. The following tables illustrate this:

Table (14)Wilcoxon test to identify the differences between the mean scores of the experimental sample in post and delayed administration of alienation scale 


\section{Global Proceedings Repository \\ American Research Foundation}

ISSN 2476-017X

Available online at http://proceedings.sriweb.org

ARF

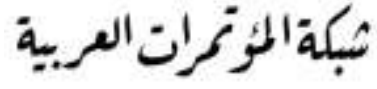

http://arab.kmshare.net/

\begin{tabular}{|c|c|c|c|c|c|c|c|}
\hline Measurement & group & number & $\begin{array}{l}\text { Rank } \\
\text { mean } \\
\end{array}$ & $\begin{array}{c}\text { Rank } \\
\text { sum }\end{array}$ & $\begin{array}{c}\mathrm{Z} \\
\text { value }\end{array}$ & $\begin{array}{c}\text { statistical } \\
\text { sig } \\
\end{array}$ & $\begin{array}{c}\text { Nature of } \\
\text { sig } \\
\end{array}$ \\
\hline Post & Positive & 6 & 5.08 & 30.5 & \multirow{2}{*}{0.310} & \multirow{2}{*}{0.757} & Non \\
\hline Follow up & negative & 4 & 6.13 & 24.5 & & & existent \\
\hline
\end{tabular}

It is evident from the previous table that there are no statistically significant differences between the mean scores of the study sample in the post and delayed administration of psychological alienation at the level (0.01), which underscores the continuing impact of the used counseling program to alleviate the psychological alienation of the experimental group.

Table (15)Wilcoxon test to denote the differences between the mean scores of the experimental sample in post and follow-up administrations of the total score of life quality scale and its of domains

\begin{tabular}{|c|c|c|c|c|c|c|c|}
\hline Measurement & group & number & $\begin{array}{l}\text { Rank } \\
\text { mean } \\
\end{array}$ & $\begin{array}{c}\text { Rank } \\
\text { sum }\end{array}$ & $\begin{array}{c}\mathrm{Z} \\
\text { value } \\
\end{array}$ & $\begin{array}{c}\text { Statistical } \\
\text { sig }\end{array}$ & $\begin{array}{c}\text { Nature of } \\
\text { sig }\end{array}$ \\
\hline Post & Positive & 8 & 7.6 & 61.5 & \multirow{2}{*}{1.119} & \multirow{2}{*}{0.263} & Non \\
\hline Follow up & negative & 5 & 5.9 & 29.5 & & & existent \\
\hline
\end{tabular}

It is clear from the previous table that there are no statistically significant differences between the experimental sample's mean scores in the post and follow up administration of life quality scale as a whole and the domains of the scale at the level (0.01). This finding underscores the continuing impact of the counseling program to improve the quality of life level of the experimental group.

\section{Discussion of results related to the hypotheses:}

The results indicate the success of the counseling program in alleviating psychological alienation and improving the quality of life among university youth of the experimental group.

The results of the study are consistent with those of: Aboud (1996), and Zahran (2003), which confirmed the effectiveness of the counseling programs in reducing psychological alienation level, and their continuing effect during the follow-up period.

The findings are also consistent with those of El-Markhi (2012), Azab (2004), Ughnyih(2012), Abu Rasine (2012), all of which confirmed the effectiveness of counseling programs and their continuing impact during the follow - up period.

The researcher attributes the program success to the techniques manipulated through which the discussion of alienation domains took place. Queer feelings and beliefs related to every domain of psychological alienation were presented in an educational way that contributed to the reconstruction of knowledge by modifying irrational ideas and beliefs, and replacing them with rational, positive, and objective ones. The techniques also contributed to the re - organization of thinking, perception and emotions besides detecting patterns of negative thinking, refuting them, and replacing them with positive and objective thoughts consistent with their circumstances and their potentials and abilities. Therefore, the students got rid of thoughts and emotions that cause alienation symptoms such as isolation, pessimism, indifference, powerlessness, meaninglessness, and rebellion. The program with its techniques provided an opportunity for students to express their feelings and beliefs, thus contributing to emotional venting and disclosing suppressions, and increasing self- confidence of the students and their self-esteem. Consequently, participants were assisted to acquire the skills that enabled them to cope with the pressures effectively and successfully. Students also were enabled to explore self - esteem, identify their goals, and develop their capacities for planning, time management, problem solving and selecting the most appropriate solutions to the problems such as self - dialogue, in addition to focusing on homework precisely defined, which represented an important part of the therapeutic work like relaxation, walking, and writing. 


\section{Global Proceedings Repository \\ American Research Foundation}

ISSN 2476-017X

Available online at http://proceedings.sriweb.org

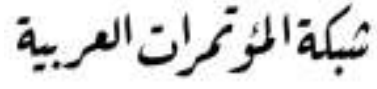

http://arab.kmshare.net/

The program contributed to improving the quality of life with all its domains. Regarding the physical level, the students were assisted to acquire proper health habits in nutrition, sleep, and sports exercises. On the social level, the students acquired social skills such as communication, dialogue, trust and a sense of belongingness. On the academic level, the program managed to provide them with the skills of planning, formulation of objectives, time management, and the development of positivity and positive thinking. On the psychological level, the program has contributed to improving the psychological life quality through emotional venting of the contents of the experience through role -play, relaxation, and group discussions allowing them to reveal what inside them indirectly, as guidance sessions helped guide the students to deal with their experiences, problems, face them, and modify their reactions. This alleviated the symptoms of alienation and improved the quality of life.

The program's success may be ascribable to the strong desire of the participants, and full conviction to participate in the program because they felt they badly needed the program and its activities, especially because they were not subjected to similar programs before. The female students' commitment to the meetings' dates and appointments, assignments, and training on social skills helped a lot in the provision of a successful atmosphere based on emotional communication and participation, understanding the panic in each student in the group, allocate enough time to talk and delve deeper into hot spots, explore the worst experiences, attention to discussion, dialogue, and raising questions. This made the students feel the positive atmosphere, and feel comfortable. Moreover, the collective sessions provided an opportunity for students to share their experiences and skills, identify others' problems, and discuss them. The program provided an atmosphere of cordial acceptance, understanding and trust between the students.

Besides, training on social skills, and refutation helped the participants to get rid of the social customs and traditions associated with many erroneous behaviors and beliefs towards many situations and issues, which may have constituted a barrier for students in raising a lot of problems and issues related to many life situations. This increased dealing with others and with their problems.

The program success can be explained in light of the skills the students learnt such as relaxation exercises, walking, giving up negative ideas and feelings, self-dialogue, the expression of ideas and feelings about all the issues raised via speaking, writing, acting, learning and practicing techniques to control the irrational and unwanted ideas, time management, and planning. Besides, role- playing was effective in unravelling the suppressions and learning appropriate ways to solve problems in such a way that fits the abilities of the participant.

The Follow up measurement results also indicate the continuing impact of the program as the female students retained the skills they mastered through the program. This is due to the quality of techniques used and the continuity of their impact, indicating the experimental group adoption of these techniques in various fields. This is perhaps due to diverse techniques included in the program, which considered the students' abilities and their needs. These also contributed to participants' commitment to what they have learned because of its positive effects.

The program provided support for female students, and opportunities to emotional vent and discharge, and engaged them in a social atmosphere that helped to increase interaction among them, and enabled them to discover new and effective ways to deal with self - esteem and with others. Moreover, subjects succeeded in breaking down the social and psychological barriers, and strengthened them to talk about the problems facing them.

The program has contributed to accustoming students to exploit their mental and intellectual abilities and potentialities through the techniques they were trained to use, which contributed to improving their perception of the quality of their lives, and develop the methods used in managing their life and developing 


\section{Global Proceedings Repository \\ American Research Foundation}

ISSN 2476-017X

Available online at http://proceedings.sriweb.org

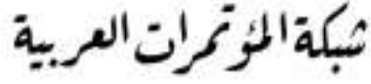

http://arab.kmshare.net/

their capabilities. These findings confirm the urgent need for using counseling programs to rehabilitate and train young people to develop their abilities and potentials because of their importance, and the positive effects, which positively reflect on the participants by giving them the opportunity to participate in various activities and events. These offered the opportunity to emotional vent, finding solutions to problems by providing a supportive social environment . The findings also emphasize that psychological counseling helps personal and social skills development, building self - confidence, positive thinking skills, getting rid of the negative experiences, which alleviate the severity of problems and troubles, and increases self acceptance and upgrade their feeling of life quality.

\section{Recommendations of the study:}

In light of the results of the study, the researcher provides the following recommendations:

1. All relevant governmental and non - governmental institutions should attend to youth by providing social and necessary psychological care, and construct counseling programs to help young people cope with the mechanisms of pressure and resist alienation, and instill affiliation, and improve the quality of life.

2 . Various media should intensify their effort by designing programs to educate young people, to protect them, and to sponsor their issues and cope with their problems.

3. Activating the role of governmental and non - governmental institutions in the provision of support for youth programs and they should allocate part of this support to meet the physical and moral needs of the youth.

4. Psychological counseling units in universities should provide psychological counseling services for young people to consolidate and strengthen their steadfastness and psychological hardiness in such a way the helps them cope with the pressures they face.

5. Increasing the number of psychological counseling centers and hiring trained psychologists to deal with young people.

6. Specialized non-governmental institutions should prepare programs for youth (especially young women) aimed at breaking the social barriers that prevent young people from voicing their issues and problems.

7. Providing counseling programs for young people focusing on the development of positive thinking skills, flexibility, dialogue and communication, tolerance, and avoiding intolerance and rigidity.

8. Conducting further studies concerned with the development of positive attitudes among young people, the factors supporting these attitudes, and other related topics.

\section{References:}

Abboud, S. (2001). The effectiveness of a counseling program in reducing alienation among adolescent students in inpatient institutions and children's villages. The Journal of the College of Education, 7 (2) 100 - 151.

Abdul Aziz, I. (2008). Quality of life indicators in their relations to mental health indicators among a sample of students from the University of Sohag. Third Arab Scientific Conference: Education and Issues of Contemporary Society, culture, Association for Development in partnership with the University of Sohag.

Abdullah, H. (2008). Quality of life in a sample of adults in light of some demographic 


\section{Global Proceedings Repository \\ American Research Foundation}

ISSN 2476-017X

Available online at http://proceedings.sriweb.org

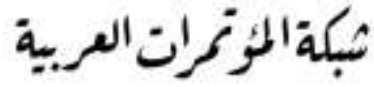

http://arab.kmshare.net/

variable. Journal of Educational and Social Studies. 14 (4) 137 - 180.

Abkar, S. (1989). The phenomenon of alienation among the students of women's colleges in the Kingdom of Saudi Arabia. PhD thesis. College of Education, Jeddah, Saudi Arabia.

Abu Halawa, M. (2010). Quality of Life: Concept and dimensions. A paper submitted to the Annual Scientific Conference of the Faculty of Education, 1 - 19, Kafr El-Sheikh, Egypt University.

Abu Racine, M. (2012). The effectiveness of a proposed training program in improving the quality of life among Educational Diploma students at King Khalid University in Abha.Psychological Counseling Journal-psychological-Counseling Center, (30) 188-234 .

Adli, K. (2006). Quality of life as perceived by the students of the Faculty of Education in Rustaq and its relationship with some variables. Proceedings of the Symposium of Psychology and Quality of Life, Sultan Qaboos University, Sultanate of Oman, 17 to 19 December,37 - 47.

Al-Ashwal, A., Azab, H., Abu Bihe, S., El-Shakhasss, A., and El-Biblawi, H. (1985). Social Change and the university youths. The Academy of Scientific Research and Technology, Cairo.

Ali, A. (2000). Social support and coping with stressful events and their relationship to adjustment to university life. The Journal of Psychology, the Egyptian publishing house, (53)6 -22 .

Allam, S. (2012). Quality of life and its relationship to job satisfaction among faculty members. Arabic studies in psychology, 11 (2) 243 - 306.

Al-Maliki, H. (2011). Depression, Personal meaning, and psychological quality of life in a sample of students in the Faculty of Education at the University of Umm Al-Qura in light of some variables. The Journal of the College of Education, Al-Azhar University ,3 (145) 244 248.

Al-Marhi, F. (2012). Effectiveness of an Counseling program to improve the quality of life among teachers of the basic education stage. Journal of Scientific Research in Education, 13(1) 54-39

Al-Shirawi, Maryam. (2013). Adaptive Behavior and its Relation to the Quality of Life of Mentally Disabled Students in Qatar. Journal of Arab Childhood, (45) 67-96.

Asaleya, M.(2001). Unemployment and its relationship with anxiety and alienation among Palestinian university graduates in Gaza Governorates. PhD thesis. Ain Shams University, Cairo.

Asimi, R. (2002). Scientific Psychological Counseling, Arab Thought publishing house, Cairo. 


\section{Global Proceedings Repository \\ American Research Foundation}

ISSN 2476-017X

Available online at http://proceedings.sriweb.org

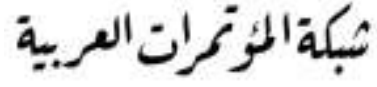

http://arab.kmshare.net/

Azab, H. (2004). A counseling program to reduce depression and improve the quality of life in a sample of future teachers. The Twelfth annual scientific conference "Education and new prospects in the education of marginalized groups in the Arab world", 20 - 28 March, 575-605.

Daugherty, T., and Lintor, J. (2003): Assessment of Social Alienation: Psychometric Properties Of the S acs-R, Social Behavior Personality, 28(4).

Development Studies Program. (1999). Challenges and priorities from the perspective of Palestinian youth. Ramallah: Birzeit University.

Dodson, W. (1994). Quality of Life Measurement in Children with Epilepsy. In: M.R.Trimble\& W.E.Dodson (Eds), Epilepsy and Quality of Life , 217-226. New York: Raven Press Ltd.

Eid, M. (1990). Psychological alienation, Cairo, The International Reesala for Advertisement.

El- Daba, T.,\& Saud, J. (2008). International study on the problem of expatriation in a sample of students of Saudi universities in light of the era of globalization. Retrieved From www.bmhh.med.sa/vb/shwthread.php/t.

El-Dabah, T., and El- Saud, A. (2008). A Factorial Investigation of the problem of alienation among a sample of students in Saudi universities in the light of globalization. Retrieved From www.bmhh.med.sa/vb/shwthread.php.

El-Kawaz, U., Mahmoud, S., Ali, M. (2011). A Comparative study of the phenomenon of psychological alienation among the first-grade students and fourth grade students at the Faculty of Physical Education. College of Basic Education Research Journal, 11 (4) $444-474$.

El-Saadi, I. (2008). The relationship between alienation and psychological Adjustment among Iraqi community in Sweden. Retrieved From www. Shmoe.com.

El-Thunayyan, A. (2009). Quality of life and future concern among undergraduate university students. PhD thesis. Faculty of Education, Department of Psychology, University of Umm Al-Qura.

Fillia, F., El-Zohairi, I. (1998). Modern Trilogy: Culture ,education, and Mass media El-Wafaa publishing house, Mansoura.

Goode, D. (1994). Quality of Life for Persons with Disabiliti. International Perspectives and Issues, In: Mitchel, D: Book Review. Journal of Intellectual, Developmental Disability, 22(1) 63-75.

Gupta, S. (2012). Alienation and Quality of Life. An Empirical Study on Personal Predictors of Loneliness. International Journal of Science and Research (IJSR) ISSN (Online): 23197064 . 


\section{Global Proceedings Repository \\ American Research Foundation}

ISSN 2476-017X

Available online at http://proceedings.sriweb.org

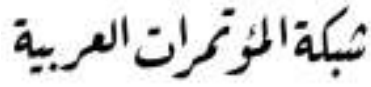

http://arab.kmshare.net/

Halaaiy,Y. (2014). Psychological alienation among university students. The scientificrefereed Journal of Ibn Rushd university, the Netherlands, (13)230- 47.Http: Retrieved From www.averroesuniversity.org/pageslAUHMAGO13devert.pdf.

Hassan, M. (2003). The psychological manifestations of alienation among high school students in Gaza governorate in light of some variables, Master Thesis. The Islamic University of Gaza, Palestine.

Hijazi,G.(2008). Psychological alienation and its relation to motivation for achievement and future orientation among Palestinian university youth. Journal of Faculty of Arts, Tanta University, (21) 994-1083

Hijazi,G., Abu Ghali, E., Mahdey, H. (2016). Future Image and Positive Thinking in Relation to Crises among Palestinian Youth in Gaza Governorates. International Journal of Research in Education and Psychology ,Volume "4" , "Issue 1" May 2016.

Hindawi, M. (2011). Social support and its relationship to the level of satisfaction with the quality of life among the physically disabled in the governorate of Gaza, master thesis. AlAzhar University, Gaza.

Ibrahim, M., and Sadiq, S. (2006). The role of sports activities in the quality of life among the Sultan Qaboos University students. Proceedings of the Symposium of Psychology and Quality of Life, 277 - 288, Sultan Qaboos University, Sultanate of Oman, 17-19 September.

Iraqis, S., and Ramadan, M. (2005). The effectiveness of a counseling program in improving the quality of life in depressed students. The Journal of the Faculty of Education, University of Tanta, 2 (34) $468-509$.

Karen, O., Lambour, G.,and Greenspan, S. (1990). Persons in Transition. In: R. L. Schalok\& M.Begab(Eds), Quality of Life Perspectives and Issues, 85-92, Washington: American Association on Mental Retardation.

Kazim, A., and El-Bahadli, A. (2007). The quality of life of Omani and Libyan university students :A comparative cultural study. The Academic Journal of the Open Arab Academy in Denmark, $3,71-110$.

Khalifi, I. (1998). Differences between Kuwaiti adolescents with behavioral problems and ordinary adolescents in terms of experience of psychological stress in childhood during the Iraqi aggression. Psychological counseling magazine, Ain Shams University, (8) 65-118..

Mahbob, H. (2012). The effectiveness of therapy by meaning in the development of mental hardiness and feeling of the quality of life in a sample of Blind female adolescents in Mecca. $\mathrm{PhD}$ thesis. Umm Al Qura University, College of Education.

Mahoney, J., Quick, B. (2001). Personality Correlates of Alienation in A university Sample. 


\section{Global Proceedings Repository \\ American Research Foundation}

ISSN 2476-017X

Available online at http://proceedings.sriweb.org

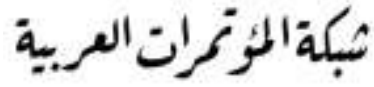

http://arab.kmshare.net/

Psychological Reports, 87(3) 1094-1100.

Majdi, H. (2009). Social support and its relationship to the quality of life for diabetics. Master thesis. University of Zagazig, Egypt.

Makhlouf, S., Banat, B. (2005). The phenomenon of alienation among Al-Quds Open University students and its relationship with some variables. Al-Quds Open University journal for Research and Studies, (6)43 - 87.

Mansi, M., and Kazim, A. (2006). The Scale of Quality of Life of university students. Proceedings of the symposium of psychology and quality of life ,63 - 78, Sultan Qaboos University, Sultanate of Oman, 17-19 December.

Mecheri, S. (2014). Quality of life from the perspective of positive psychology: An analytical study. Journal of Social Studies and Research, University of the valley, (8) 215-237.

Mohamed, A. (2000). Cognitive- behavioral therapy. Cairo: Dar al-Rashad.

Moursi, A. (1997). Identity crisis and psychological depression among university youth. Psychological Studies Journal, Volume VII(3).

Mursi, J. (2006). The effectiveness of a training program inproviding female students with some social skills to alleviate psychological stress. The Egyptian Journal of Psychological Studies.16 (51) $213-263$.

Mustafa, H. (2009). Improving the quality of life using a counseling program based on choice theory. the Ismailia College of Education Journal, (14) 157 - 196.

Nuaysa, R. (2012). Psychological alienation and its relationship to psychological security: A field study on a sample of Damascus University students living on campus. Journal of the University of Damascus, 28(3)113 - 158.

Oghnieah, S. (2012). A Counseling program to improve the quality of life among Libyan university students. The Journal of Scientific Research in Arts, (13) $82-110$.

Orte, C., March, M., and Vives, M. (2007). Social Support, Quality of Life and University Programs for Seniors. Educational Gerontology, 33(11) 995-1013.

Rayce S., Holstein, B., Kreiner, S.(2009). Aspects of alienation and symptom load among adolescents. Eur J Public Health, 19(1) 79-84.

Rayce, S., Holstein, B., Kreiner, S. (2008). Aspects of alienation and symptom load among adolescents. European Journal of Public Health. 19(1) 79-84.

Sahel, R\& Hanoura, E. (1998). Trauma level and its relation to personal values, alienation and psychological disorders among young people, field study on a sample from Kuwait. The 5th 


\section{Global Proceedings Repository \\ American Research Foundation}

ISSN 2476-017X

Available online at http://proceedings.sriweb.org

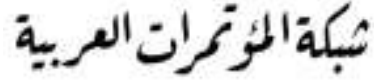

http://arab.kmshare.net/

International Conference of Psychological Counseling, 1-27, Cairo: Psychological Counseling Center, Ain Shams University.

Sexton, M. (1983) . Alienation and reated personality characteristics. Journal of Clinical Psycho, 5(2).

Shata, A. (1993). The theory of alienation from the perspective of Sociology, University Youth Foundation, Alexandria.

Shirawi, M. (2013). Adaptive behavior and its relationship to the quality of life among the lightly mentally disabled pupils in Qatar. Arab Children Magazine, (45) 67 - 96.

Vahedi, a., and Nazari, M. (2011). The Relationship between Self-Alienation, Spiritual WellBeing, Economic, Situation and Satisfaction of life: A Structural Equation Modeling . Iranian Journal of Psychiatry and Behavioral Sciences, (IJPBS), 5(1) .

Watfa, A. (1998). Manifestations of alienation in the Arab personality. The world of Thought Journal, The National Council for Culture, Arts and Letters, Kuwait.27 (2).

WHOQO Group. (1995). The World Health Organization Quality of Life Assessment (WHoQo). Position Paper from the World Health Organization Social Science and Medicine, 41, 1403-1409.

WHOQO Group. (1998). The World Organization Quality of Life Assessment (WHoQol). Development and General Psychometric Properties. Social Science and Medicine, 46, 15691585.

Zahran, S. (2002). The effectiveness of a cognitive- emotionalpsychological counseling program of Mental Health in correcting beliefs about alienation among university students. $\mathrm{PhD}$ thesis. Faculty of Education, Mansoura University, Damietta.

Zahran, S. (2003). The effectiveness of a psychological counseling program of Mental Health incorrecting beliefs about alienation among university students. Psychological Counseling Journal, Psychological Counseling Center, Ain Shams, (17)1 - 59.

Zahran, S. (2004). Mental Health counseling to correct the feelings and beliefs about alienation. The world of book publishing house, Cairo. 